\title{
Henry Wallace and the Farm Crisis of the 1920s and 1930s
}

\author{
LAUREN SOTH
}

\begin{abstract}
American agriculture slumped in economic depression most of the time between the world wars. In these two decades an entirely new relationship was created between farming and urban society and government. Henry Agard Wallace of the Iowa Wallaces was the undisputed intellectual and political leader of this change. To understand the place of Henry Wallace in the evolving political economy of agriculture during the interwar years, we must first transfer ourselves mentally back in time sixty years. That's quite a difficult journey, considering how much American life has been altered-even for those of us senescent citizens who lived through those decades.

The first thing to recall is that nearly one-third of the people of the United States lived on farms-less than 3 percent do so today. There were $61 / 2$ million farms as compared with under $21 / 2$ million today. These large changes in numbers actually understate the radical nature of the upset in organization of agriculture from then to now. At least two-thirds of today's $2 \frac{1 / 2}{2}$ million farms are operated by part-time farmers whose families get more of their income from nonfarm sources than from sale of farm products. Most of these "farmers" more accurately would be called factory workers, lawyers, teachers, carpenters,
\end{abstract}


or insurance salespersons. If the census definition of a farm were increased from the current $\$ 1,000$ worth of sales of farm products per year to $\$ 2,500$, the number of farms would be reduced by a million. Furthermore, the business of the remaining $11 / 2$ million farms is heavily concentrated in the larger business units. Half a million farms produce and sell 85 percent of the farm products in commercial channels.

The large-scale, industrialized farm had not arrived in 1921 when Henry Cantwell Wallace became United States secretary of agriculture and his son, Henry A., became editor of Wallaces' Farmer. There were some big wheat farms on the Plains and a few large cotton establishments in the South. But agriculture was made up almost entirely of small to middle-sized, truly family-size farms. The horse was king of farm power. The difference between farm and city in those days was a vast gulf. Farm families were isolated from urban living, mostly without plumbing, electricity, and public services of all kinds including hard-surfaced roads. Farm families provided much of their own food, fuel, clothing, and entertainment. They were less commercialized and more self-sustaining. They didn't buy fertilizer, pesticides, seed, and factory-blended livestock feeds. This is the kind of agricultural society in which the Wallaces, beginning with the revered Uncle Henry, patriarch of the family, had risen to leadership. In preparing the way for a discussion of Henry A. Wallace's pre-eminent career in guiding public policy about agricultural affairs, one must sketch the family foundations on which he built.

Henry Wallace, "Uncle Henry," the grandfather, and Henry Cantwell Wallace, the father, were traditional Republicans, somewhat maverick-ish though. In the early twentieth century, they often lined up on the progressive or liberal side of the party. But they believed in the protective tariff and in "sound money." Uncle Henry, a contemporary of James Baird Weaver and William Jennings Bryan, stoutly opposed their easy-credit, soft-money, monetization-of-silver policies. Yet considering his fierce opposition to business monopoly, railroad management, the middlemen, the meat packers, and the grain trade-malefactors on the Populists' hit list-one would have expected Uncle Henry to agree on money and tariffs. All the Henry Wallaces were backers of Theodore Roosevelt in the 1912 


\section{Farm Crisis/Soth}

election; their devotion to the Republican party was not as strong as their devotion to the progressive policies of Roosevelt on conservation, trust busting, and aid for farmers.

Young Henry or "H. A.," to distinguish him from H. C., or Harry, began his lifelong study of the economic aspects of farming soon after he graduated from Iowa State College in 1910 and started work on the family newspaper. During the war he developed a set of cost-price ratios, relating the price of corn to the price of hogs, for example, to publish as guides for farmers in planning production. When the United States entered the war in 1917, President Wilson appointed Herbert Hoover as food administrator and Hoover named $\mathrm{H}$. C. Wallace as head of an advisory committee on pork supply which was running short of the wartime demands. Hoover attempted to meet the problem with a propaganda campaign, appealing to the farmers' patriotism to raise more hogs. Wallace argued that farmers needed financial incentive and based his proposal to Hoover on the hog-corn ratio worked out by his son. He said the price ratio needed to be 13 to 1 (per hundred-weight of hogs to bushels of corn) if the required pork was to be produced. Hoover opposed this idea at the start but later said he would "try" to stabilize the price of hogs at the 13 to 1 ratio. Wallace and most farmers took this as a promise, and when the Food Administration quit trying to keep hog prices at the desired level in the fall of 1916, they thought they had been betrayed. This was the beginning of a long period of antagonism between the Wallaces and Hoover, intensified when Harry Wallace and Hoover found themselves on the Harding cabinet together.

An interesting evolution of thought took place in the Wallace family during Henry C. Wallace's tenure as Harding's secretary of agriculture. The secretary of agriculture began to lose faith in the protective tariff for agriculture. Early in the administration he had supported an increase in farm-product tariffs, a campaign promise of President Harding and the Republican party. But gradually he came to see the absurdity of tariffs providing protection for commodities that were exported in large quantity, such as wheat. Very little corn was exported at that time, but the foreign market for corn converted into pork and lard was vital to corn belt farmers. The sharp decline in exports to Europe after the close of the war had put crushing pressure on farm commodity prices. 
Probably the strongest influence on the secretary was his oldest son, who had long since concluded that the protective tariff system was injurious to agriculture. It increased the cost of manufactured goods farmers bought and hurt farm exports by limiting foreign dollar supplies. After the war, America's transition from a major debtor nation into the world's largest creditor nation strengthened Henry A. Wallace's argument for low tariffs: Foreign debtors of the United States could not pay their debts unless they could earn dollars by selling goods to America. Moreover, they would have to severely curtail their purchase of American products in order to save dollars for paying war debts. Like John Maynard Keynes, Henry A. thought the heavy reparations would force the Germans into crippling reductions of their imports-including agricultural goods from the United States.

One of Harry Wallace's first objectives as secretary was to convene a conference of farm and business leaders to examine the crisis facing farmers. Commodity prices crashed after the war and land prices were following in a tumult. Many farmers had bought land on the wave of optimism that came with soaring prices during the war. "This is only the beginning," farmers would say. "Our good land is all taken up; populations are growing; you can't lose on land investment." But they could. In their editorials in the late war years, the Wallaces were advising farmers to pay off debts. They warned about a coming price crash, such as the one that followed the Napoleonic wars. But few listened. When prices of corn and hogs collapsed, while mortgage payments and interest remained fixed, bankruptcies and foreclosures spread like wildfire.

The new secretary thought something should be done about farm credit and the prices of farm products. Harding was not enthusiastic about calling a conference and making a big thing out of the farmers' plight. Hoover and Andrew Mellon in the cabinet were opposed, also. But one day after persistent pressure from his agriculture secretary, the good-natured president gave in. At the finish of a game of golf, which Wallace and Harding often played together, the president said, "Go ahead with your agricultural conference, Hank." This was the inauguration of the famous Agricultural Outlook Conferences which have been held by the USDA annually ever since. It also 
was the beginning of the Bureau of Agricultural Economics and attention to economics in the USDA, which had been wholly devoted to improving farm production.

Harry Wallace had helped organize and lead the Corn Belt Meat Producers Association as early as 1905 and had been the permanent executive secretary until he became secretary of agriculture. Then he turned over the job to his oldest son, seemingly by right of primogeniture. The organization originated mainly as a pressure group to fight for lower freight rates for livestock but became an advocacy group on broader issues affecting corn belt farmers. Naturally, the Corn Belt Meat Producers Association was invited to the outlook conference. A. Sykes, the longtime president of the group, was scheduled to address the meeting. The elder Wallace, having doubts about Sykes's ability to write a good speech, asked his son to help Sykes prepare one. Henry A. wrote a slashing attack on the protective tariff bill then in the Senate Finance Committee. When the father saw the text, he told his son the tariff comment would never do and would have to be deleted-and it was. As editor of Wallaces' Farmer, however, Henry A. had the full speech set in type and printed for the next edition before he left for Washington. The attack on the administration's tariff bill appeared in the paper soon after the conference closed. Although the senior Wallace had disavowed any connection with the paper's editorial policy when he took office, Harding was not pleased about this criticism which seemed to come from his own cabinet. The agriculture secretary's only comment to his son, however, was, "Henry, have a heart."

This episode marked a turning point in national agricultural policy to emphasize international affairs and was premonitory of the world viewpoint of Henry A. Wallace throughout his life. As the 1920 s wore on, with depressed farm prices, stagnant export trade, and building surpluses, the young editor of Wallaces' Farmer continued to hammer on the stupidity of American foreign trade policies.

At the first outlook conference the farm groups disagreed on the issue of fixing prices of agricultural products. The fiery John Simpson, then president of the Oklahoma Farmers Union and later national president of the Union, wanted the government to peg prices at cost of production. Harry Wallace and the 
Farm Bureau were strongly opposed. This was the beginning of a long battle between farm groups about price fixing versus other means of raising prices of farm products. The conference also was the start of the movement to gain for farmers "fair exchange value" for their products - the birth of the parity idea. George Peek of the Moline Plow Company spoke in favor of doing this by means of a two-price plan, dumping farm surpluses overseas in order to maintain a domestic fair-exchange price. That was the origin of the McNary-Haugen bills that were introduced in the middle twenties and vetoed twice by President Coolidge.

A book on agricultural prices by Henry A. Wallace, published in 1920, attracted much interest in the farmers' price problem. The book dealt with cost-price ratios and used multiple correlations to analyze and explain agricultural pricing. Wallace said that "so far as farmers are concerned, the object of studies of this kind is, first, to play the price game as well as capital and labor; and second, to cooperate with capital and labor to enforce prices roughly equivalent to cost of production to the end that supply and demand may operate more smoothly."

The first outlook conference set the stage in the struggle for what was called in those days " "farm relief." The attitude of the Republican administrations in the twenties was negative. Hoover and Harding favored government action only to help farmers organize and develop better marketing programs. But in this conference, held under a Republican administration, many farm policy ideas sprouted that were put into practice later in the New Deal-all except production control which everybody was trying to avoid.

$H_{\text {enRY }}$ A. WAllace, the dedicated internationalist, was leery of export dumping as well as of protective tariffs. But as the farm depression worsened he began to accept the plan invented by George Peek and Hugh Johnson of the Moline Plow Company for an agricultural export organization to dispose of United States farm surpluses abroad. Anything that offered some promise of farm relief and broke the ideological barrier against government action became more palatable to both conservatives and liberals, free traders and nationalists alike. 
Out of a background of agrarian traditionalism and conservatism, Henry $\mathrm{A}$. Wallace grew more and more into pragmatism, less hidebound by ideology than his father and grandfather who themselves were far from being rigid ideologues. He was willing to try new schemes that seemed practical in an economic sense and workable politically. He was skeptical of radical economic plans that he felt would disrupt the capitalistic system. He sensed as keenly as any politician ever has that whatever the government did had to be acceptable to a large preponderance of the people or it would fail.

During the last half of the 1920s Wallaces' Farmer settled on McNary-Haugenism as the practical vehicle for dealing with the mounting surpluses and depressed finances of agriculture. In the May 25, 1928 issue of the paper, as the legislation was on the verge of passing Congress for the last time, the editor printed the text of the bill. The accompanying story described the plan: "It provides that the surplus may be bought up, dumped abroad, stored or disposed of in any way to get it off the home market and so bring up the home market price. The loss involved in this operation is to be met by an equalization fee levied on the units of the commodity benefited."

Note the use of the word "dumped" which was not considered pejorative by the editor at that stage of the struggle for farm equality. In his editorials, Wallace often spoke of the McNary-Haugen plan and other similar proposals as ways to "make the protective tariff effective for agriculture." This rationalization enabled Republicans, who were deeply committed to the party's protective tariff philosophy, to justify their support for farm relief. They could be in favor of tariffs for manufacturers and at the same time be in favor of compensatory action to make the tariff effective for farmers, without appearing to violate the GOP faith. Making the tariff effective became the premier slogan of the farm relief advocates. This propaganda line and the visible distress of farmers in the Republican districts of the North swung many Republican congressmen onto the McNary-Haugen bandwagon.

But Coolidge vetoed the bill for the second time. In the next edition of Wallaces' Farmer, June 1, the editor ran nine editorials about the iniquity of the veto and a tenth on how farmers 
ought to get out and vote in the primary election to show their feelings about the matter.

Henry Wallace made the equalization-fee principle the main issue of the campaign for entry of the federal government into supply management for agriculture. In a speech sponsored by the League of Women Voters on NBC network radio a month earlier, he had said, "Thoughtful farmers are anxious to borrow the centralizing power of government . . . but they do not want to raid the Treasury . . . because they do not believe in subsidy. They want to pay for this kind of thing by themselves by means of an equalization fee." Intervention of the government into the private business of farming, he said, was necessary because of the protective tariff and the power of large corporations. This was a theme that he continued to stress throughout the New Deal years and later. "I see much merit," Wallace said, "in applying the ideals of old-fashioned democracy, greatly lowering the tariff on manufactured products, opening up our gates to immigration, taking away all possible favors from our large corporations and doing everything else possible to restore a primitive state of competition."

Another factor contributing to the surplus of farm production, Wallace thought, was the single-minded promotion of production efficiency by the land-grant agricultural colleges and the USDA, ignoring the over-supply problem and neglecting economic research and education. In his May 1928, NBC radio network address, he indulged in this sarcastic comment:

The state and federal governments are spending 100 million dollars a year to make our farmers more efficient. . . . They are guilty of the grossest negligence if they do not face the problem thus created. . . . If this continues another 10 years, I would not be surprised . . . to see many farmers rise up in their anger and demand that the government spend its money on making city people efficient rather than farmers.

This remark and similar comments in his writings made Wallace not the most popular of farm editors among the presidents and deans of the agricultural colleges.

At this same time, of course, Wallace was perfecting his own experiments in hybrid corn and in 1926 had started his own seed business to improve the efficiency of the corn growers. He 
saw no inconsistency in farm research to improve production and the creation of unwieldy surpluses which depressed prices, despite his sardonic jab about making city people more efficient rather than farmers. Apparently, what he meant was that the colleges should study ways and means to balance supply and demand in addition to their work on production methods. Maybe, he suggested, we should have the government buy up the poor farmland which was then in crops and plant it to trees and grass. That marks another plank in the Wallace platform for agriculture that runs through his editorship and political activity. In this, we may be sure, he was drawing on the embedded philosophy of his grandfather about a permanent farming system. It fit in well with the need to reduce production, as viewed by the grandson in 1928 .

We see in the "writings and speeches of Henry Wallace in the year 1928 the analysis and arguments on which the New Deal in farming was based: The protective tariff system and an inward-looking, nationalistic economic policy had brought agriculture to financial disaster. The large corporations, with their power over industrial prices abetted by the tariff, were able to squeeze the lifeblood out of free-market farming. The logical and best solution would be to strike down the tariff walls, provide credit for foreign buyers of farm products, and restore a competitive economy. That being impossible, then agriculture needed "the centralizing power of government" to manage its own supplies and raise prices. Finally, government should help farmers to protect the nation's soil resources and to improve their marketing through cooperatives and better credit institutions. Production control was in the wind, but at the time of the 1928 presidential election it got little attention.

T He editor of Wallaces' Farmer in 1928 was still tentative about political party preference. The family paper had long disavowed party allegiance and did not support candidates for election. As late as September 1928, the editor was cautious about alienating his Republican readers, although he and the Corn Belt Committee, a joint lobby group of farm leaders in which Wallace was active, had been saying favorable things about Al Smith and the Democrats, because the Democrats had expressed support for the McNary-Haugen idea in their 
Houston convention. (Hoover and the GOP remained opposed.)

Wallace illustrated his political caution in a speech to the Iowa Farmers Union convention. He said, "I honestly think that Hoover will carry Iowa by 200,000 votes. In view of that I think it would be a fine thing for farmers who are thinking about the welfare of Iowa agriculture, if they would plunk their votes solidly for Smith, in view of the fact that there is that much margin." He was peeved when the Des Moines Register quoted him as saying, "The farmer of the United States can best serve his own ends by throwing his influence to Governor Alfred E. Smith for president." He seems to have been insistent on making clear that the only reason he suggested voting for Al Smith was that Hoover would carry the state anyway.

Readers of Wallaces' Farmer must have realized that the editor favored the Democrats on the basis of farm policy, but prohibition was a big issue, too. On November 2, the paper's last pre-election editorial weighed the farm relief and prohibition issues, obviously favoring the Democrats on the former and expressing fear that the eastern press and the politicians would think that Iowa farmers supported Hoover's farm policy even if they were voting for his keep-prohibition policy. The editor said the big question was whether a large majority for Hoover would help or hurt the farm campaign in Congress. He clearly thought it would hurt.

From 1928 to 1932 the farm economic situation declined alarmingly as the entire commercial world crumbled into what was been called ever since the Great Depression. Wallace realized that programs to store or dispose of surplus farm products would not be enough to achieve farm prosperity. He became more interested in monetary and general economic policies.

Since 1921 he had been a vice-president of the Stable Money League founded by the famous economist, Irving Fisher of Yale University. Fisher and George F. Warren of Cornell University advocated a "commodity dollar" instead of the gold standard. Wallace was attracted to this idea because of the consequences of tight money he could see in agriculture. The Stable Money League later became the Stable Money Association. This association (of which Franklin A. Delano, Franklin Roosevelt's uncle, was chairman from 1929 to 1933), and especially member 
George Warren, had considerable influence in convincing FDR to devalue the dollar.

Wallace was critical of the hard money policies of the Federal Reserve Board in the early 1930s. In a leaflet he wrote in 1930 entitled "The Causes of the World Wide Depression of 1930 ," he urged the Federal Reserve Board to increase its buying of bonds to expand the availability of bank credit. He expounded at length on the harm being done to farmers by the decline in prices. He noted that the Federal Reserve authorities had done their best to discourage stock speculation and could hardly be blamed for the crash of 1929 . He praised the board for lowering rediscount rates and increasing bank reserves, but he thought it was too conservative and should do more. He was farsighted, much more so than most of his contemporaries, but he did not realize that what he called the depression of 1930 would turn out to be a depression of the 1930s, in part attributable to timid and unimaginative monetary policy.

In his paper on causes of the depression, Wallace acknowledged that there had been some sense in the GreenbackerPopulist cries for free silver and soft money led by Weaver and Bryan in the late nineteenth century. The declining price level after the Civil War, which caused great suffering among farmers, made the inflationist proposals "essentially sound in the recognition of real human wrongs." Wallace was still dubious about policies that could bring about continuous inflation, but he had advanced his thinking beyond the goldstandard dogmas of the past.

Henry Wallace was looking beyond the supplymanagement problems of the farmer. In his essay on causes of the depression, he of course did not neglect the Smoot-Hawley tariff of 1930 . He forecast correctly that it would lead to retaliation and a general slowdown of international trade. He quoted with approval a Swedish newspaper's comment that the new tariff law was "the most terrible blow against the economic life of the world." He listed the higher tariffs enacted in many European countries in response to Smoot-Hawley.

Wallace wrote that there was justification for tariff protection for infant industries when the United States was young, as advocated by Alexander Hamilton and Henry Clay, but the modern American economy could not justify such protection. 
He quoted the older Republican philosophy as enunciated by William McKinley, who said that whenever a product passed under the control of a trust, it should be deprived of tariff protection. "The present-day Republicans," wrote Wallace, "are radicals who have departed from the principles of the founding fathers. Today we find the Republican party allowing great trusts to use the tariff for price-fixing purposes."

In this essay, as in his other writings of the time, Wallace showed that his concern for social justice and fairness was not limited to the farming population. He worried about the jobless factory workers and the consumers who would be hurt by an undue rise in the cost of food-this at a time when farm prices were collapsing. He was looking to the future. He saw danger in the too rapid introduction of new technology which replaced humans in the work force.

In all of his eight years as secretary of agriculture, Henry Wallace was more than just the farmer's hired man in Washington. He engineered and managed the greatest change in the relatioship between farmers and government ever. He provided the opportunity for farmers to climb out of the depression slough, and the farm people knew what he was doing for them. But he also was a leading figure in the whole New Deal, concerned with the whole society.

$\mathrm{D}$

URING THE Hoover years, one of the farm relief plans connected with the McNary-Haugen battles was given a tryout. A Federal Farm Board was established in 1929 to buy up surpluses and support prices. It had a fund of $\$ 250$ million, and it proved to be a failure. "The Farm Board experiment in sustaining wheat prices," Henry Wallace wrote later, "was started at the worst possible moment, although no one fully realized it at the time." Farm leaders felt the Farm Board was a weak compromise to avoid doing something more fundamental but were willing to give the administration an opportunity to carry out its plan. When wheat prices continued to slide in spite of the Farm Board's buying and a similar operation by the Canadian wheat pool, farm leaders turned toward production control.

W. J. Spillman of the Department of Agriculture, a protégé of Harry Wallace, and several academic economists were working on a plan to cut farm production. Even Alexander Legge of 
the International Harvester Corporation, who was chairman of the Farm Board, recognized the impossibility of supporting prices without control of supply. John D. Black of Harvard, M. L. Wilson of Montana State College, and Beardsley Ruml of the University of Chicago were prominent in developing what they called the Voluntary Domestic Allotment Plan. This was the basis for the Agricultural Adjustment Program in the New Deal. Franklin Roosevelt became interested in the idea of controlling farm production to meet demand, and in a campaign speech at Topeka in September 1932, he advocated the essentials of the domestic allotment plan. Wallace wrote in his most famous book, New Frontiers, published in 1934, that Rexford Tugwell, of the "brains trust," learned about the plan from M. L. Wilson and explained it to FDR.

After the election, Roosevelt asked Wallace and other farm leaders to meet with Marvin Jones, chairman of the House Agriculture Committee, to see if something could be done on a farm program by the lame duck Congress before the inaugura.tion. That effort failed. When the new administration came into power in March 1933, the Agricultural Adjustment Act sailed through rapidly and became law on May 12, 1933. Wallace gave high praise to the farm leaders who worked with him on passing this legislation, especially Ed O'Neal of the Farm Bureau, "who worked so unceasingly to heal the ancient breach between the Democratic farmers of the South and the Republican farmers of the Middle West."

The bill, Wallace wrote, was "the logical crystallization of the long struggle for adequate farm legislation." He saw it as experimental. He said farming people were proceeding with confidence and felt that Congress and the president would give them new legislation or make repairs in the old if the act "did not prove sufficiently powerful and flexible."

The AAA, with its allotments of crop acreages and hog numbers, was widely supported by farmers and their organizations. The hard times farmers suffered during the postwar years, culminating in the severe price collapse of the early thirties, made conservative farmers desperate for action even if it involved socialistic programs and government regulation.

Secretary Wallace surprised the country and probably himself by demonstrating stout leadership and skillful admini- 
strative capacity. He organized the new AAA rapidly and went into action immediately to cut the cotton crop for 1933 and the wheat crop for 1934. About ten million acres of cotton, a fourth of the total, were to be plowed under with the money to reimburse farmers coming from the new processing tax. Wheat farmers had a poor crop coming on and little money coming in, so the AAA decided to pay them benefits in advance if they signed up for acreage reduction in 1934. These were revolutionary moves that shook the nation.

Wallace wrote later that he had mingled feelings about the plow-up campaign. "It was an amazing demonstration," he wrote, "of what a united people can do because they know there is no acceptable alternative. I could tolerate it only as a cleaning up of the wreckage from the old days of unbalanced production. Certainly none of us ever want to go through a plow-up campaign again, no matter how successful a price-raising method it proved to be."

The cotton plow-up caused only a tremor in public opinion, however, compared with the slaughter of the sows and the pigs in 1934. Wallace and his associates planned to cut corn acreage and reduce the breeding of sows in 1934, but the effects of that on farm income would be felt only late in the year or in 1935. Farmer committees in the corn belt suggested to Wallace that the government buy up and slaughter five or six million little pigs and two million piggy sows as an emergency measure. The edible portions of the carcasses would be distributed to families on relief.

The ensuing public uproar exceeded anticipation. Wallace wrote, "Doubtless it is just as inhumane to kill a big hog as a little one, but few people would appreciate that. They contended that every little pig has the right to attain before slaughter the full pigginess of his pigness. To hear them talk, you would have thought that the pigs were raised for pets. Nor would they realize that the slaughter of the little pigs might make more tolerable the lives of a good many human beings dependent on hog prices."

The slaughter plan was carried out, further dramatizing the new administration's and Henry Wallace's willingness to violate the conventional doctrines in order to give farmers relief. As it turned out, the severe drought in 1934 did more to cut corn pro- 
duction than the acreage allotments. The slaughter of the pigs speeded up an inevitable adjustment of pork production to feed supply.

During the first years of government intervention into the private business affairs of farm operators and owners-at a time of continuing worldwide economic stagnation and high unemployment-every step by the government was on unexplored ground. There were fierce disputes in the Department of Agriculture and fierce disputes in the farming and business communities. Very early it became apparent that processors, shippers, and handlers of farm products would fight the production limitations. Among the farm organization leaders, Wallace had to contend with the cost-of-production price-fixing advocates on the one hand and the McNary-Haugen export dumpers on the other.

George Peek, the old McNary-Haugenite, was named first administrator of AAA, with Charles J. Brand, a former USDA official and later National Fertilizer Association executive, as control plans. Peek had thought he should be named secretary of agriculture. It was not a happy headquarters team, and before 1933 ended, both Peek and Brand were gone. Wallace, often called a dreamer and idealist, showed that he could be a tough and practical administrator.

At a later time when Chester Davis was head of AAA, conflict arose between the managers of the adjustment program, and liberal lawyers and social scientists in USDA who wanted to do more for small farmers, hired farm workers, and black people in the rural South. The Triple-A was led by people who had worked with the major farm organizations and commercial farmers, agricultural establishmentarians. They were primarily concerned with supply adjustment; their critics, who had little farming background, were more interested in social reform. They objected to the sugar contracts, marketing agreements, and other programs that they thought were benefiting the rich at the expense of the poor. In the South, AAA contracts were signed by the landlords who received the cash benefits. Tenants sometimes did not get their fair share, and with cotton acreage cut back, many were thrown off the land.

Jerome Frank, who headed the AAA legal division, wrote a new interpretation of the cotton contracts making it illegal for a 
tenant to be displaced. Davis was out of Washington when this was done. When he returned he was outraged and reversed Frank's order. He told Wallace that the whole farm recovery program would be harmed if the Frank order stood, since he thought the cotton growers would pull out of AAA. He said Frank, Gardner, Jackson, and several other members of the AAA staff who were protégés of Rexford Tugwell and Felix Frankfurter, would have to be fired. Wallace reluctantly agreed.

Philosophically, Wallace undoubtedly sided with the critics of AAA. Both before he was secretary of agriculture and afterward, he was a champion of the poor and disadvantaged. It must have galled him to realize that the AAA, while benefiting the South as a whole, was making life more miserable for the sharecroppers. But he didn't want to lose Chester Davis and he wanted to keep plowing ahead toward the main goal of better balanced agricultural production. If the Frank group had its way, Wallace knew he would lose the support of the agricultural main line, which he could not afford to do.

The ruckus over landless tenants helped to pave the way for establishment of the Resettlement Administration which was headed briefly by Rexford Tugwell, the intellectual leader of the group which Davis fired. Later this became the Farm Security Administration and now has evolved into the Farmers Home Administration. Roosevelt appointed a committee on farm tenancy, with Wallace as chairman, and this led to the Bankhead-Jones Tenancy Act of 1937, providing funds for loans to small farmers and displaced tenants. The concern for production control and stabilizing income of commerical agriculture was supplemented in the second New Deal term with more attention to poor farmers, hired farm labor, and poor consumers, although the commercial farm programs remained dominant then as they have since.

The next crisis in the farm supply management program came on January 6, 1936 when the Supreme Court declared the Triple-A unconstitutional. The court, said Henry Wallace in his book, Whose Constitution?, published later that year, had denied agriculture the federal mechanism for coordinating production. In an earlier radio speech, he said he had no quarrel with the court's legal reasons but did have with the effects of the decision on social justice. 
The court had ruled that the processing taxes which were enacted to pay the cost of acreage adjustments were unconstitutional. Wallace and his associates did not accept this decision as removing all power of government to deal with farm overproduction. In a matter of days, the AAA was out on the road explaining to farmers that the balanced production goal would be sought through incentives to convert cropland to soilconserving uses. Wallace said that the Supreme Court had "launched the soil conservation program probably two years sooner than sound planning called for."

All along, Wallace had considered the original AAA program to be a stopgap, to be replaced whenever conditions allowed. In his book, New Frontiers, published in 1934, he wrote:

I would not mind seeing the processing tax and acreage control abolished in 1936 if we have something better to take its place. But unless we have built up greatly increased foreign purchasing power by reducing tariffs, or unless we start loaning money outside the United States to enable foreign nations to buy our surplus, I am afraid that dropping the processing tax and acreage control in 1936 would result, with the ordinary run of weather, in a repetition within a few years of the 1932 situation.

But when the blow fell, Wallace and his staff came up with a new Soil Conservation and Domestic Allotment Bill, which was soon passed. The acreage reduction system went on about as before, without the processing tax and with more emphasis on soil conservation.

The county committees made up of local farmers proved capable beyond expectations in administering the crop adjustment programs. The complicated tasks of setting allotments, making commodity loans, and checking compliance were performed with remarkable smoothness and few complaints of unfairness. The Wallace theory that farmers would be more willing to cooperate with neighbors than outsiders proved sound. He was confident they would see that rules were obeyed. The local committee system still is functioning, but on a more professional basis. At the start, with six million farms in the country, the committees were faced with mammoth, unfamiliar jobs of information, explanation, and enforcement. Wallace called it a new form of economic democracy.

As the experiment in supply management for agriculture 
proceeded through the 1930s, Wallace kept two goals in front of farmers and the public. One was the long-term protection of soil resources; the other was the idea of balance or stability which he had written about so much in the twenties. He wanted farmers to be able to adjust their market supplies to maintain a fair income but not to gouge the consumer.

Actions following the drought of 1934, Wallace claimed, showed that the Agricultural Adjustment Act was really an adjustment act and not just a reduction act. Drought wiped out the surpluses of grain. What the AAA had planned to do in two or three years, the drought did in one. But the adjustment in this crude and haphazard way was disastrous to millions. Something was needed to smooth out the cycles. Even in late 1934, after the worst drought in history, Wallace warned that without control over acreage of corn in 1935, there would be a large expansion in plantings and danger of renewed surplus: The total yield might amount to as much as 2.7 billion bushels. (That seemed a tremendous crop in those days, long before the recent eight-billion-bushel crops.) He did not want a cut in acreages, but he warned against over-expansion, and a program was needed for that.

That was not enough. An adjustable inventory of grain also was required. Wallace advocated what he called an evernormal granary. What he meant, of course, was an everabnormal granary. In New Frontiers, he wrote:

We began to develop in our minds the idea that the government, through the Commodity Credit Corporation, should not loan money at the market price or above market price except in years of large crops or undue price demoralization; and that during the following year or the year thereafter, any surplus accumulated as a result of loaning without recourse could be used effectively in restoring a fair price, by the means I have described: that is, offer it in lieu of benefit payments to farmers cooperating in acreage control.

By this method, Wallace said, "We could prevent burdensome supplies from accumulating, and the corn price from breaking unduly, by using corn supplies, accumulated in years of large crops, to reduce the acreage the following year."

Underlying the adjustment of supplies in the short run, Wallace kept reminding the nation, was the necessity for long- 


\section{Farm Crisis/Soth}

range planning of soil and water resource use. He could become quite lyrical in talking about the soil in nearly all his works, including the book, Whose Constitution? He quoted Thomas Jefferson that "soil is the mother of man" and spoke often of the concern of the nation's early leaders for good care of the land. He wrote of the difference between the soil conservation problems of the broad, continental United States and of Europe. Europe does not suffer the sweeping winds and the variability of rainfall that the Middlewest and Great Plains undergo.

Wallace said that "unfettered individualism results in exploitation of natural resources." But the Supreme Court said farming is a local matter, Wallace noted with scorn, and asked, "Is there no way for the capitalistic system to develop a mechanism for taking thought and planning action?" He suggested that the country might need a Council for the General Welfare to speak up against special interests and parochial interests on such matters as foreign trade, natural resource policy, and agricultural stabilization policy. No one was more conscious of the emergency nature of many of the New Deal farm policies, and no one was more anxious to convert to long-range planning than Henry Wallace. He said the government should develop "incentives to bring about the gradual and permanent shift of excess plow land to grass and trees."

Henry Wallace was an unusual combination of farsighted idealism and practical politics. Under his administration of the Department of Agriculture, American farming was started on a path toward parity-parity not in the narrow price-index sense but in income, living conditions, and bargaining power-with the nonfarm population. Wallace provided the vision and the action for the realization of the goals of early American leaders-that farming would not be a second-class occupation or way of life.

The country had the good luck to bring to national leadership a corps of people called New Dealers who could take a new course in battling economic depression without ideological blinders. Henry Wallace was the exemplary New Dealer; a thorough pragmatist, he feared nothing but fear itself.

He opposed Roosevelt's recognition of Russia, because he thought that it might encourage a revolt of the masses in Europe who were suffering from the depression and would look upon 
the Soviet Union as a success. He came to believe later that cooperation with the Soviet Union was essential to world peace, but he never lost his skepticism about communism.

He was a devoted internationalist, but he was practical enough to accept the nationalist $\mathrm{McNary}$-Haugen plan as the feasible way to farm relief. He strongly backed Cordell Hull's trade agreements approach to lower trade barriers.

He hated race discrimination, but he went along with the southern politicians in conduct of unequal farm programs in order to get them started.

He worked to raise prices of farm products, but he was always conscious of the danger of exploitation of the consumer.

The driving force behind Henry Agard Wallace was social justice. The overriding problem of social justice from his point of view in the 1920s and 1930s was the disadvantage of farming people in a country increasingly dominated by corporate business and unionized labor. He was an agrarian specialinterest advocate, to be sure, but not to the exclusion of other interests. He was a person who truly believed that government under our Constitution had a responsibility for the general welfare.

\section{Sources}

Benedict, Murray R. Farm Policies of the United States, 1790-1950. New York: The Twentieth Century Fund, 1953.

Black, John D. Economics for Agriculture: Selected Writings. Cambridge, MA: Harvard University Press, 1959.

Lord, Russell. The Wallaces of lowa. Boston: Houghton-Mifflin, 1947.

Saloutos, Theodore. The American Farmer and the New Deal. Ames: Iowa State University Press, 1982.

Schapsmeier, Edward L. and Frederick H. Henry A. Wallace of lowa: The Agrarian Years, 1910-1940. Ames: Iowa State University Press, 1968.

Walker, J. Samuel. Henry A. Wallace and American Foreign Policy. Westport, CT: Greenwood Press, 1976.

Wallace, Henry A. The Causes of the World Wide Depression of 1930. Des Moines: Wallaces' Farmer, 1931.

- - - America Must Choose. New York: Foreign Policy Association and Boston: World Peace Foundation, 1934.

- - New Frontiers. New York: Reynal \& Hitchcock, 1934.

- - Whose Constitution? An Inquiry Into the General Welfare. New York: Reynal \& Hitchcock, 1936.

- - The Price of Vision: The Diary of Henry A. Wallace, 1942-1946. Foreword by John Morton Blum. Boston: Houghton-Mifflin, 1973.

Wallaces' Farmer. 1928 passim.

Winters, Donald L. Henry Cantwell Wallace as Secretary of Agriculture, 1921-1924. Champaign: University of Illinois Press, 1970. 
Copyright of Annals of Iowa is the property of State of Iowa, by \& through the State Historical Society of Iowa and its content may not be copied or emailed to multiple sites or posted to a listserv without the copyright holder's express written permission. However, users may print, download, or email articles for individual use. 